\title{
Potential of phytofactors to mitigate rumen ammonia and methane production*
}

\author{
M. Szumacher-Strabel ${ }^{1}$ and A. Cieślak \\ Poznań University of Life Sciences, \\ Department of Animal Nutrition and Feed Management, RUMEN PULS \\ Wotyńska 33, 60-637 Poznań, Poland
}

(Received 26 May 2010; accepted 16 August 2010)

\begin{abstract}
The increase in the intensity of ruminant production determines changes in the rumen feed conversion and thus, among other, may increase pool of greenhouse gases emission. The ineffective digestion process and changes in the legislation processes implicate the action tends towards the limitation of rumen ammonia and methane production. In the last few years there is an increasing interest of nutritionists in bioactive plant factors - phytofactors as natural feed additives that can modify the rumen fermentation processes, improve the protein metabolism and, at the same time, reduce ammonia production and emission, and curb methane production and emission to the atmosphere. High diversity of bioactive phytofactors contained in many plant species has been identified as a potential factor affecting the above-mentioned processes.
\end{abstract}

KEY WORDS: ruminants, essential oils, saponins, ammonia, methane, environmental pollution

\section{INTRODUCTION}

The extensive discussion about the effect of anthropogenic factors on the environment, especially in the aspect of climate changes resulting from the increasing pool of greenhouse gases (GHG), provokes some thought on the contribution of intensive agricultural production, including ruminant production,

\footnotetext{
${ }^{*}$ Supported in part by the Ministry for Science and Higher Education, Grant No. N N311 239638

${ }^{1}$ Corresponding author: e-mail: mstrabel@jay.up.poznan.pl
} 
to the above-mentioned process. Anthropogenic emissions of GHG have increased since the beginning of the Industrial Revolution (c. 1750) and further increases are possible as world-wide fossil fuel combustion continues to rise (Place and Mitloehner, 2010).

Ruminants produce large amounts of protein consumed by humans. In the European Union $25 \%$ of meat and nearly $100 \%$ of milk come from ruminants. Great importance of ruminants as food producers is related to their ability of utilizing low-quality feed and thus converting poor-quality substrate into highquality product (Greathead, 2003). The ability results from symbiotic relationships between the ruminants and the populations of rumen microorganisms able to consume and ferment cellulose, hemicellulose and pectins.

The increase in the intensity of ruminant production determines changes in the composition of a feed ration, i.e. reducing the amount of green forage rich in structural carbohydrates, and increasing the amount of starch in a feed ration. In order to maintain high production level and for the synthesis of microorganism protein, ruminants require also increasing amounts of nitrogen and exogenous amino acids. Thus the symbiosis between a ruminant and microorganisms populating the rumen in the case of extensive animal breeding becomes disturbed. The increasing demand for nutrients, mainly structural carbohydrates and protein, resulted in a decrease in the symbiosis effectiveness and hence the animals, despite the increased demand, are not able to utilize excessive amounts of protein and energy. The ineffective process of protein digestion leads to the increased rumen ammonia production, while the disturbed proportions of feed carbohydrates and changes in their fermentation result in the increased methane production. Both the mentioned gases belong to the group of so-called greenhouse gases, whose level of production in the rumen and thus the amount emitted to the atmosphere, is linearly dependent on the composition of a feed ration.

The announcements of legislation changes affect the implementation of socalled cow tax by the European Commission, a tax on farm ruminants. Its purpose is to limit the emission of greenhouse gases to the atmosphere. The current proposal imposes $€ 5$ per a ton of the emitted gas, which implies charges of $€ 13$ per a head of dairy cow, $€ 7$ per a head of non-dairy cattle, $€ 1$ per a head of sheep. The described changes result from so-called Kyoto Protocol (1997; entered into force in 2005) supplementing the United Nations Framework Convention on Climate Change, an international agreement on the prevention of global warming. Under the protocol provisions, countries which have ratified the Protocol, have committed to reduce their emissions of carbon dioxide, methane, nitrous oxide, HFC and PFC (gases causing the greenhouse effect) by the negotiated values collated in an annex to the Protocol (by at least 5\% below 1990 levels - Article 3, paragraph 1) by 2012. In case of a deficit or a surplus of GHG emissions, the agreement signatories 
are obliged to enter into 'trade exchange' - resale or repurchase of the limits of other countries. If the Kyoto Protocol is fully implemented, the average global temperature is predicted to decrease by $0.02-0.28^{\circ} \mathrm{C}$ by 2050 . In comparison to the emission level of 1988 - the base year for the former socialist countries, Poland is to reduce its emission by 6\%. California of the United States of America became the first state that adopted a regulation requiring the mandatory reporting of GHG emissions - Assembly Bill 32 (California Global Warming Solutions Act of 2006) (Place and Mitloehner, 2010).

Thus the reduction of the amount of emitted GHG is related to the issue of the reduction of ammonia and methane production and emission by ruminants that has two scientific and practical aspects worthy of consideration: 1. increasing the utilization of basic feed ration components (protein and energy), and 2 . environmental protection.

In the last few years there is an increasing interest of nutritionists in bioactive plant factors - phytofactors as natural feed additives that can modify the rumen fermentation processes (e.g., defaunation), improve the protein metabolism and, at the same time, reduce ammonia production and emission, and curb methane production and emission to the atmosphere. High diversity of bioactive phytofactors contained in many plant species has been identified as a potential factor affecting the above-mentioned processes. No effect of the phytofactors has been fully confirmed since it depends on many factors, including:

1. from an animal: species and production purpose and thus concentration of structural carbohydrate in a feed ration, type of the used feed, latitude of occurrence of an animal,

2. from a plant: type of a factor, its structure and activity, synergistic or antagonistic relations with other feed ration components.

The interest in phytofactors results from mainly its properties and the ability of influencing the rumen environment, however, a very significant reason that additionally determined the trend and broadening of the research on the use of plants and their biologically active compounds, were subsequent legislation factors related to the ban on the use of antibiotics and other additives in animal nutrition and the trend towards natural additives, previously observed particularly in Europe.

With the assumption that the global market of antibiotic growth promoters in its peak in 1996 was worth USD $237 \times 10^{6}$ (Greathead, 2003), it is not difficult to predict the implications of an increasing interest in alternative plant compounds. In 1996 the US market used about 90 tons of these substances of the market value of $€ 413,000$ (Frost and Sullivan, 2000, after Greathead, 2003), and a substantial increase has been observed since 1996, intensified after 1 January 2006, when a directive of the European Union entered into force that banned the use of antibiotic growth promoters in animal nutrition in the European Union. 
However, the interest in plants as carriers of biologically active compounds is not new. So-called 'ethnoveterinary' and 'ethnomedicine' for centuries has been using various forms of plants. The first information on the medicine based on plants comes from China in 5000 BC (Greathead, 2003), from Mesopotamia in 2600 BC (Newman et al., 2000), and also from Egypt in about 1550 BC (Davidson and Naidu, 2000). At that time mainly the antiseptic and antibacterial properties of plant biologically active compounds were used, for example in maintaining hygiene or body mummification. The natural medicine was widely used (especially in Western Europe) until the first half of the $20^{\text {th }}$ century, when a trend towards synthetic medicines that were effective, patentable and highly profitable, occurred (Tyler, 1999). The first reports on the possibility of using plant biologically active compounds for modulating changes in the rumen of ruminants come from 1911 when Hoffman and Evans published their study. Another reports appeared in the 1960s when authors described the effect of secondary plant metabolites (Borchers, 1965) and essential oils (Oh et al., 1967; Nagy and Tengerdy, 1968) on the rumen fermentation processes, including protein metabolism. However, due to the difficulties (time and costs) of the isolation from frequently very complex extracts and characterization of individual active factors, and then their chemical synthesis, the interest in these compounds was decreasing. Since about 1970, a trend towards synthetic, effective and profitable substitutes of plant components has begun. Until the turn of the $21^{\text {st }}$ century, very little studies were published on the possibility of using phytofactors in broadly defined animal nutrition, while much research was conducted on the use of synthetic antibiotic growth promoters. Since about 2000, a feed antibiotic retreat has been observed, whose main reasons include: 1. a resurgence of interest of pharmaceutical companies in plants, 2. increasing interest from the animal industry, and 3. increasing legislation surrounding the use of the so-called medicinal feed additives. The reasons for final changes in the legislation on the use of infeed antibiotic growth promoters, confirmed by a directive of the European Union (1832/2003/CE; European Commission, 2003), were as follows: 1 . to combat the development of microbial resistance to antibiotic drugs and to examine the consequences to human health, 2. response to the consumer pressure to eliminate the use of non-plant xenobiotic agents from animal diets, 3. toxicity and lack of selectivity in relation to microorganisms, and 4. lack of microbial adaptation ability.

The interest in the potential of phytofactors to mitigate rumen ammonia and methane production is related to their possible effect on the microorganisms directly participating in the processes of nutrient fermentation in the rumen. One of the main groups of the compounds are secondary plant metabolites, which, depending on their structure, origin and mechanism of action, may be divided into several groups that include essential oils and saponins. 


\section{THE POSSIBILITIES OF THE REDUCTION OF AMMONIA PRODUCTION AND EMISSION BY RUMINANTS}

The most important source of nitrogen for the growth of ruminal bacteria is ruminal ammonia. For most of the bacteria it is the only source of nitrogen, which makes them independent from the sources of protein, peptides or amino acids (AA). However, excessive ammonia supply in the rumen (over requirement), the effect of an excess of feed protein and low efficiency of its utilization, results in the excretion of the surplus amount of ammonia in the urine. It is estimated that about 0.3 unit of $\mathrm{N}$ consumed by a dairy cow is excreted in the urine (Lapierre et al., 2005). Ammonia is absorbed through the rumen wall into the blood, carried to the liver, and converted to urea, the greater part is excreted in the urine. Some urea is returned to the rumen via the saliva, and also directly through the rumen wall. Hence the amount of ammonia nitrogen is strongly correlated with $\mathrm{N}$ losses (James et al., 1999). Place and Mitloehner (2010) indicate that there are great variations in the ammonia emissions between farms, depending on animals' diets (VandeHaar and St-Pierre, 2006). Cows consuming $419 \mathrm{~g} \mathrm{~N}$ daily are characterized by a similar level of milk production as cows that consume $516 \mathrm{~g} \mathrm{~N}$ daily. Nevertheless, $74 \%$ of the consumed additional $\mathrm{N}$ is excreted as urinary urea-N, which could be lost to the environment as ammonia emissions (Castillo et al., 2001). The reduction of the amount of ammonia emitted to the environment can be achieved by the modification of the feed ration composition, thus reducing the loss of feed ration protein and the amount of ammonia in the excrement. The addition of natural plant biologically active compounds is a promising source of phytofactors affecting the processes of nitrogen transformations in the rumen. It is expected that these compounds will improve the protein utilization through limitation on proteolysis, peptidolysis and deamination and also by restriction of microorganism activity, e.g., hyper-ammonia producing bacteria or protozoan population. The analyses of the above-mentioned compounds have been conducted both in the in vitro and in vivo conditions, and the obtained results were subject to the used method, duration of the experiment, animal species, type of a feed ration, and also the type and amount of the phytofactor used.

\section{The effect of essential oils on the reduction of ammonia production in the rumen}

As it has already been mentioned, one of the first studies on the effect of essentials oils and pure secondary plant metabolites deriving from them were conducted by Borchers (1965) and Broderick and Balthrop (1979) that analysed the effect of thymol addition on nitrogen transformations in the in vitro conditions. The obtained results indicate the possibilities of AA accumulation and a decrease 
in the ammonia $\mathrm{N}$ concentration that suggest the inhibition of AA deamination by ruminal bacteria. Busquet et al. (2005) determined the effect of the essential oil from Syzygium aromaticum and found a decrease in large peptide amount and no effect on the ammonia concentration, which suggests that Syzygium aromaticum can reduce the peptidolytic activity of ruminal bacteria. However, the analysis of the effect of the main secondary plant metabolite contained in the essential oil from Syzygium aromaticum - eugenol, did not show the expected result, which suggests the existence of some synergistic relationships between the components of the essential oil that determine its positive effect. In addition, Busquet et al. (2006) analysed the effect of the addition of the essential oil from Origanum vulgare and its active ingredient - carvacrol. Both the essential oil and the secondary plant metabolite decreased ammonia production in the rumen. The possibility of the occurrence of synergy or antagonist reactions is not the only explanation of the phytofactor effect. A study by Castillejos et al. (2006) indicated that the effect is also subject to the concentration of a given substance $(5,50,500$ and $5000 \mathrm{mg} / \mathrm{l})$ and to its chemical structure. Due to the presence of the hydroxyl group, phenolic compounds exhibit the highest antimicrobial activity (Benchaar et al., 2008).

In a response to the requirements of animal production, the animal feed industry has launched on the market animal feed additives containing mixtures of secondary plant metabolites. McIntosh et al. (2003) analysed the effect of the addition of $\mathrm{Crina}^{\circledR}$ ruminants preparation and observed a decrease in the speed of amino acids deamination in the in vitro conditions, when casein acid hydrolysate was incubated in batch cultures of ruminal fluid collected from the cows fed a silage-based diet supplemented with $1 \mathrm{~g} / \mathrm{d}$ of this commercial mixture. According to Rossi (1994, after Benchaar et al., 2008), the Crina ${ }^{\circledR}$ ruminants supplement contains $100-300 \mathrm{~g} / \mathrm{kg}$ of phenolic compounds including cresol, resorcinol, thymol, guaiacol and eugenol. McIntosh et al. (2003) also suggested that the effective concentration of biologically active compounds in in vitro experiments to affect the protein metabolism should be higher than $35 \mathrm{~g} / 1$ of fermented rumen fluid. According to Benchaar et al. (2008) that level may be difficult to achieve in the in vivo conditions.

In the research on the possibility of using essential oils as factors reducing ammonia production and emission to the atmosphere, also the duration of an experiment should be noted. The favourable changes observed in the first 24-48 $\mathrm{h}$ of an experiment are not always confirmed in long-term tests. Cardozo et al. (2004), Busquet et al. (2005) and Benchaar et al. (2008) suggested that the rumen microbial population may adapt to an experimental factor already after 6-7 days of an experiment.

The above-presented examples of the effect of essential oils and individual active substances on nitrogen transformations in the rumen were related to their 
influence on the particular groups of both gram-positive and gram-negative bacteria. Hyper-ammonia producing bacteria (HAP), bacteria strictly specialized in ammonia production, are the most proteolytic among rumen microorganisms. For the first time hyper-ammonia producing bacteria were isolated in New Zealand and Australia in sheep, cattle and deer consuming green fodder (Attwood and Reilly, 1995). The bacteria sparsely populate the rumen (less than $0.01 \%$ of the rumen bacteria population), but are characterized by very high metabolic activity (Russell et al., 1988). According to the literature, they are responsible for $50 \%$ of protein decomposition in the rumen and thus ammonia production (Hart et al., 2008). Fourteen morphologically diverse species have been identified but the greatest activity is attributed to Clostridium sticklandii, Clostridium aminophilum and Bacteroides, gram-positive bacteria whose presence in the rumen depends on the type of a feed ration and the latitude of occurrence of animals.

Many authors have proved potentially favourable effect of a mixture of essential oils on the activity and number of hyper-ammonia producing bacteria and other proteolytic bacteria. McIntosh et al. (2003) demonstrated that the mixture of essential oils in the form of Crina ${ }^{\circledR}$ ruminants preparation inhibits the growth of Clostridium sticklandii and Peptostreptococcus anaerobius. Additionally, the research showed different effect of essential oils on the individual bacteria. The mixture of essential oils in the form of Crina ${ }^{\circledR}$ ruminants preparation less effectively influences Clostridium aminophilum. According to Wallace (2004), the intensity of the essential oil effect on HAP and other proteolytic bacteria depends on the concentration of protein in a feed ration. The author also suggests that the effect of essential oils in the rumen may be regulated by their influence on Ruminobacter amylophilus, amylolytic and proteolytic organism sensitive to the essential oils, and that Ruminobacter amylophilus may play a significant role in the process of colonization of the substances rich in protein and starch in the rumen.

The above-described results of nitrogen transformations in the rumen are related mainly to the favourable bacterial effect. On the other hand, protozoa play a negative role in the protein utilization by ruminants (Benchaar et al., 2008), since they consume and digest a substantial number of ruminal bacteria thus reducing the net flow of bacterial protein from the rumen to the duodenum (Ivan et al., 2000b). Since protozoa have the ability to perform the processes of proteolysis and deamination, the rumen defaunation (elimination of protozoa from the rumen ecosystem) results in an increase in the amount of nitrogen of microbial origin reaching the duodenum. According to Ivan et al. (1992), the amount of bacterial protein reaching the duodenum of defaunated sheep is higher by $35 \%$ in comparison to the non-defaunated ones. 


\section{The effect of saponins on the reduction of ammonia production in the rumen}

The effect of saponins on the concentration of ammonia nitrogen and protein transformations in the rumen is directly related to the interactions between protozoa and bacteria and to the decreased flow of nitrogen of bacterial origin from the rumen. Additionally, it is subject to the type of the used saponins. Despite saponins show potential to influence protein transformations in the rumen that is often not proved statistically (Newbold et al., 1997), research do not always confirm the hypothesis (Hristov et al., 1999). Saponins are weakly absorbable in the rumen (Cheeke, 1996) but may be degradable (Hart et al., 2008) and hydrolysable (Miles et al., 1992).

Saponins as the most effective known factor naturally present in plants that enables to limit the number of rumen protozoa, may have significant influence on the protein utilization by ruminants. As it has already been mentioned, protozoa engulf bacteria and thus increase the utilization of microbial nitrogen in the rumen, which reduces the pool of amino acids reaching the duodenum (Ivan et al., 2002a). At present it is difficult to achieve total defaunation, and there is no available commercial preparation that would initiate the process efficiently and safely (Teferedegne, 2000; Ivan et al., 2002a). A research by Leng et al. (1992), after Hart et al. (2008) indicates that using saponins as a defaunating agent is effective only during their administration. In the experiments lasting a week, administration of supplements containing saponins resulted in a decrease in the number of protozoa in the sheep and goat rumen, however, after the supplementation the number of protozoa came back to its initial state. A similar tendency has been proved in studies by Teferedegne et al. (1999) and Ivan et al. (2004). In addition, differences in the effect of saponins from various plants on the protozoan populations of animals living at different latitudes are observed. Odenyo et al. (1997) found no effect of saponins contained in Sesbania sesban in the sheep living in Ethiopia, which consumed that plant in a daily ration, while the number of the rumen protozoa in the sheep living in Great Britain has decreased as a result of using the same supplement - Sesbania sesban (Newbold et al., 1997). The effect of saponins on protozoan populations is ambiguous and, apart from the aforementioned factors, also depends on the type of the protozoa. The response to saponins of many protozoa groups so far has not been revealed (Patra and Saxena, 2009).

\section{POSSIBILITIES OF REDUCTION OF METHANE PRODUCTION AND EMIS- SION BY RUMINANTS}

Methane amounts to $18 \%$ of the total pool of greenhouse gases (GHG), and its concentration during the last few decades has increased by $151 \%$ and the process 
is still increasing (Wuebbles and Hayhoe, 2002). In the animal production as much as 95 to $97 \%$ of methane comes from ruminants (Johnson and Ward, 1996). It has also been reported that enteric methane is the most important GHG emitted at the farm scale in the ruminant production system (50 to 60\%) (Ogino et al., 2007). The data collated by Jensen (1996) indicate that the daily methane production by ruminants ranges from 301 (sheep of the weight of $40 \mathrm{~kg}$ ) to 2301 (cow of the weight of $500 \mathrm{~kg}$ ). Methane amounts from 30 to $40 \%$ of the pool of gases produced by ruminants. The quantity of methane production depends on the intensity of transformations in an organism, production purpose and type of the feed used (Islam and Begum, 1997). Loss of methane from the fermentation processes in the rumen, emitted to the atmosphere, deteriorates feed utilization and thus decreases the economic effect of animal maintenance. Johnson and Johnson (1995) assessed the energy loss deriving from the process of fermentation as 2 to $12 \%$ of feed gross energy. Hence, decreasing the production of enteric methane in ruminants without altering animal production is desirable both as a strategy to reduce global GHG emissions and as a means of improving feed conversion efficiency (Dong et al., 2010; Martin et al., 2010).

The process of methanogenesis occurs mainly in the rumen and its conditions include anaerobic environment and the presence of microflora (Hegarty, 1999). As a result of interspecific symbiosis between methanogens and bacteria, protozoa or fungi, among other things, transfer of $\mathrm{H}_{2}$ originating from the cells of the abovementioned microorganisms to methanogens occurs. Methanogens use, e.g., $\mathrm{CO}_{2}$ for the reduction of $\mathrm{H}_{2}$, and the energy obtained in the process is used for the formation of ATP. Owing to the process of methane production in the rumen, low concentration of $\mathrm{H}_{2}$ is maintained in the rumen atmosphere, which favourably affects carbohydrate transformations in this environment (Wolin and Miller, 1988; Ushida and Jouany, 1996). The available data states that a cow utilizes even 8001 $\mathrm{H}_{2}$ daily for methane production in the rumen (Hungate, 1967).

Since methanogens are also a significant group of microorganisms participating in the process of methanogenesis, many research on the analysis of the amount of methane produced is related to the analysis of effect of a given factor on the population of methanogens. Methanogens prevailing in the rumen of farm animals include microorganisms of the genus Methanobrevibacter and Methanosaricina, particularly the species: Methanobacterium formicicum, Methanobrevibacter ruminantium, Methanosaricina barkeri, Methanosaricina mazei and Methanomicrobium mobile (Stewart et al., 1997). However, the development of modern molecular techniques proves that a ruminant species determines a methanogen that predominates in the rumen (Zhu et al., 2007). Nevertheless, it should be taken into account that imperfections of the currently used detection techniques in some cases do not allow to perform unambiguous interpretation 
of the obtained results. Many authors suggest the implementation of strategies that result in the reduction of adverse effect of the process of methanogenesis on the environment in ruminants: 1 . directly by decreasing the amount of emitted methane per a unit of consumed feed and 2. indirectly by increasing the animal performance with the same level of methane emission (Kreuzer and Soliva, 2008) brak w references. More detailed solutions include: 1. reduction of hydrogen production without adverse effect on feed digestion, 2. alternative, more favourable to a host/an animal utilization of hydrogen, 3. reduction of both the number and the activity of methanogens (Martin et al., 2010). Many research centres in the world conduct research on the methods of reduction of methane emission to the atmosphere. Lately the interest in the use of phytofactors to achieve the aim has increased.

\section{The effect of essential oils on the process of methanogenesis in the rumen}

Information on the effect of essential oils on the process of methanogenesis in ruminants is ambiguous (Patra and Saxena 2009, 2010). The rumen ecosystem, due to various interactions within it, can differently react to the used factors modulating fermentation, including the process of methanogenesis. It has been proved by both the current studies and the studies from the 1950s and the 1960s. Early experiments on the effect of essential oils on the process of methanogenesis in the rumen ecosystem revealed no effect of essential oils (40 ppm) on the population of Methanobrevibacter smithii (Hobson, 1969). The results obtained by Newbold et al. (1988) demonstrated that the increasing level of essential oils may be a direct reason for reduction of the population of the microorganisms participating in methane formation in the rumen (Methanobrevibacter smithii PS; ATCC 35061). However, according to some authors, it is mainly the used amount and the source of essential oils that are responsible for the result of reduction or lack of reduction of methane production (Evans and Martin, 2000; Chaves et al., 2008). Crane et al. (1957) demonstrated that the addition of a secondary plant metabolite, limonene, can limit the growth of the microorganisms participating in methane formation in the rumen, thus resulting in the reduction of its production. The research by McIntosh et al. (2003) showed that the limitation on the number of Methanobrevibacter smithii (measured indirectly through the amount of produced methane) occurred only after using the highest addition (1000 ppm) of the commercial mixture of essential oils, while the lower doses $(5,10,20$, $40,80,160 \mathrm{ppm}$ ) did not adversely affect the population of Methanobrevibacter smithii. Other studies similarly revealed that the highest used addition $(400 \mu \mathrm{g} / \mathrm{l})$ of the essential oil from Thymus vulgaris and Origanum vulgare (thymol) strongly inhibited the process of methanogenesis in the in vitro conditions, resulting in the 
93\% reduction of the amount of produced methane (Evans and Martin, 2000). However, it should be emphasized that lower thymol doses of 50, 100 and $200 \mu \mathrm{g} / 1$ did not result in any changes in methane production. Similar tendencies have been observed by Macheboeuf et al. (2008), who analysed the effect of the essential oils extracted from Thymus vulgaris, Origanum vulgare, Cinnamomum verum and Anethum graveolens. The lower doses of the above-mentioned substances did not result in the reduction of the process of methanogenesis in the in vitro conditions, while the higher doses reduced the methane production even by $98 \%$ (the addition of essential oils extracted from Cinnamomum verum in the amount of $5 \mathrm{mmol} / \mathrm{l}$ ). In addition, Macheboeuf et al. (2008) also noted that moderate doses of the used essential oils may also result in a decrease in methane production but to a proportionally limited extent. Similar tendencies were found in the studies where the increasing amount of limonene ( 40 and $400 \mathrm{mg} / \mathrm{l}$ ), the main active compound of fir oil (Abies alba), resulted in the linear reduction of the process of methanogenesis, respectively by 26 and 30\% (Cieślak et al., 2009). The reduction of methanogenesis was accompanied by the limitation on the general methanogen population (on average by $25 \%$ ). In the same research a lower dose of the analysed factor $(4 \mathrm{mg} / \mathrm{l})$ did not significantly affect the general methanogen population and methane production in the in vitro conditions. The authors point out that not only the highest, but also moderate amounts of the used experimental factor can modulate the methanogen populations and thus the process of methanogenesis in the rumen environment (Cieślak et al., 2009). The addition of limonene may adversely affect rumen microorganisms, including the protozoa that deliver a substrate in the form of $\mathrm{H}_{2}$ for the formation of $\mathrm{CH}_{4}$. In some other research, the use of peppermint oil (Mentha piperita) in concentration of 1 or $2 \mu 1 / 1$, respectively resulted in the linear reduction of the level of methanogenesis (on average by $61 \%$ ) together with the limitation on the number of methanogens (on average by $82 \%$ ) and a decrease in the protozoan activity measured by 14C-radio-isotopic technique (Agarwal et al., 2009). On the basis of the obtained results, the authors suggest the inhibition of the protozoan population that results in the adverse influence on the population of methanogens associated symbiotically with ciliates. It should also be noted that the lowest concentration of peppermint oil $(0.33 \mu 1 / 1)$, apart from the reduction of methane production by $20 \%$, had no effect on the general number of methanogens. In the analysed group, a doubling of the number of microorganisms was noted in comparison to the control group. On the basis of the research, it can be concluded that a lower dose of peppermint oil can favourably affect the groups of methanogens that exhibit lower activity in the process of methane formation. Similar conclusions have been drawn by other researchers that carried out a phylogenetic analysis of the rumen ecosystem, proving a tendency towards an increase in the diversity of methanogens in comparison to Methanosphaera stadtmanae, Methanobrevibacter smithii and some uncultured groups with cinnamaldehyde, garlic, and juniper 
berry oil supplementation (Ohene-Adjei et al., 2008). The observed tendencies can be attributed to the diversity of methanogens. Supplementation of ruminant diets with essential oils may alter the diversity of rumen methanogens without affecting the methanogenic capacity of the rumen. Ohene-Adjei et al. (2008) also do not exclude the possibility of influence of essential oils in the activity of methaneproducing genes. However, Calsamiglia et al. (2007) take note of the fact that the amount of essential oils should be so selected as not to disturb the effectiveness of the processes of microbial fermentation and to effectively modulate, among other things, the process of methanogenesis by its chemical properties and participating in protein and carbohydrate transformations in the rumen.

\section{The effect of saponins on the process of methanogenesis in the rumen}

The research with the use of secondary plant metabolites, including saponins from various sources, i.e. Yucca schidigera, Sapindus saponaria, Frangula alnus, Sapindus rarak, indicate a possibility of the effect of these compounds on the process of methanogenesis in the rumen (Ningrat et al., 2002; Śliwiński et al., 2002a; Hess et al., 2003, 2004; García-González et al., 2008, 2010; Wang et al., 2009). One of the hypotheses explaining the observed reduction of methane production in the rumen of ruminants fed rations supplemented with saponins is their effect on the protozoa living in mutual symbiosis with methanogens (Francis et al., 2002). According to Hegarty (1999), methanogens associated with rumen protozoa are responsible for 9 to $25 \%$ of the total methane production during anaerobic fermentation in the rumen. Additionally, rumen methanogens exist on the surface of ciliate protozoa and are responsible for between 9 and $37 \%$ of enteric methane production (McAllister and Newbold, 2008). The above hypothesis has been confirmed both in the in vitro and in vivo experiments (Lila et al., 2003, 2005; Hess et al., 2004). According to Lila et al. (2003, 2005), supplementation of feed rations consisting of meadow hay and concentrate with saponins reduces methane production in steers on average by $12.7 \%$, while in the in vitro conditions during $24 \mathrm{~h}$ incubation the reduction amounted from 15 to $44 \%$. Similar observations were made by Hess et al. (2004), who analysed the effect of supplementation of low-quality grass hay (Brachiaria dictyoneura) with legume foliage (Cratylia argentea) or the fruit of the multi-purpose tree Sapindus saponaria. They stated that the daily methane production was reduced (on average by $6.5 \%$ ) due to the adverse effect of saponins from Sapindus saponaria on protozoan populations. According to Wallace et al. (1994), saponins can be used even as a factor totally eliminating the population of rumen protozoa. The effect of saponins on protozoa indirectly participating in the process of methanogenesis in the rumen may depend on the chemical structure of saponins that enables the interactions with cholesterol of membranes of eukaryotic cells, which leads to the destruction of a cell (Cheeke, 1996; Wina et al., 2005). The research that analysed the effect of saponins from 
Yucca schidigera confirm that thesis. The results of the in vitro (Pen et al., 2006) and in vivo (Hristov et al., 1999) experiments revealed a reduction in the number of protozoa after using the extract of Yucca schidigera (YSE). It should also be noted that mere short- and long-term defaunation reduces methane emission by about 20\% (Morgavi et al., 2008). Furthermore, the inhibition of methanogenesis by saponins from Sapindus saponaria was more effective in defaunated animals (29\%), than in the animals with naturally numerous rumen microflora (14\%) (Hess et al., 2003a). Thus it was proved that a decrease in methane production is not a result of a limitation on protozoan number only, which was confirmed in other research both in the in vitro and in vivo conditions (Hristov et al., 2003; Baah et al., 2007; Benchaar et al., 2008). A probable reason for the observed differences may be: 1. a degree of bacterial cell degradation (Newbold et al., 1997), 2. saliva production disorder (Teferedegne, 2000), and 3. the possibility of saponin deactivation by animal saliva amylase (Odenyo et al., 1997). A significant factor that affects the effectiveness of saponins may be also the amount used in a feed ration (Hristov et al., 2004; Benchaar et al., 2008). It is confirmed also by research of other authors which used the supplementation of feed rations of sheep with YSE saponins (98 mg/kg diet, Desert King International Product, USA), showing reduction of methane emission by $15 \%$ (Wang et al., 2009). However, in other research, a much greater dose of saponins from Yucca schidigera $(1380 \mathrm{mg} / \mathrm{kg}$ diet) resulted in statistically insignificant reduction of methane emission by about 12\% (Pen et al., 2007). Similar results were obtained by Holtshausen et al. (2009) in their experiment on cows fed with the addition of saponins of YSE (Desert King International Product, USA) in the amount of $10 \mathrm{~g} / \mathrm{kg}$ DM. The obtained results are explained by both the level of the supplement used and possible differences caused by the source of origin of saponins. That was proved also in an earlier study by Śliwiński et al. (2002), who found no reduction of methane production resulting from the used saponin doses. Other factor that determines the effect of saponins may be the composition of a feed ration (Goel et al., 2008). The process of methanogenesis can be more effectively curbed with the use of a feed ration with a predominance of concentrate in comparison to a feed ration with a predominance of forage. However, it should be taken into account that a higher share of concentrate will generate a smaller amount of methane than a feed ration rich in forage. Additionally, ambiguous results in the experiments with the use of saponin extracts or plants containing saponins may be related to the waning antiprotozoal effect that is directly subject to the time of effect of these substances in the rumen (Newbold et al., 1997; Teferedegne et al., 1999). Protozoa are not resistant to saponins (Newbold et al., 1997), but these substances can undergo the process of detoxification by other microorganisms, including bacteria, and that time is an important part of the process (Terefedegne et al., 1999; Teferedegne, 2000). Hence the results obtained in a short-time research may not completely characterize the saponin effect on the process of methanogenesis. In addition, saponins, due to their chemical structure, 
may display antibacterial properties by reducing the number of bacteria producing $\mathrm{H}_{2}$ thus resulting in the inhibition of $\mathrm{H}_{2}$ production - a substrate for methane formation (Wang et al., 2009). The reduction of the population of microorganisms associated with the process of methanogenesis is not tantamount to the reduction of methane production. This hypothesis is confirmed by Hess et al. (2003), who found that the supplementation with Sapindus saponaria saponin in the amount of $100 \mathrm{mg} / \mathrm{g}$ DM reduces methanogenesis by about $20 \%$ with no influence on the population of methanogens in the in vitro conditions. Limitation on methanogenesis without a decrease in the amount of methanogens was also observed by other researchers that used saponins from tea seeds (Hu et al., 2005; Mao et al., 2010). No adverse effect of tea saponins on pure cultures of methanogens prevailing in ruminal fluid (Methanobrevibacter ruminantium) was observed (Guo et al., 2008). These authors attribute the results of their observations to the possible diminished activity of a methane-producing gene by the supplementation with saponins. The presented examples illustrate lack of unequivocal results of the conducted research. Wina et al. (2005) demonstrated that saponins from the fruit of Sapindus rarak decrease the concentration of methanogen RNA only in the highest dose concentration $(4 \mathrm{mg} / \mathrm{ml})$, while lower concentrations have no influence on the populations of these microorganisms, which proves the significant importance of the amount of the saponin used. A significant element which should also be taken into account is the type of a solvent used for saponin extraction (Patra and Saxena, 2010). Saponins from Sapindus murkossi extracted with the use of ethanol, more effectively affect the process of methanogenesis in comparison to water and methanol extracts (Agarwal et al., 2009). High effectiveness in the reduction of methane production in the rumen ecosystem is possible to achieve also with the use of unextracted plant saponins, provided in the form of leaves or seeds (Sesbana sesban; Trigonella foenum-graecum) (Goel et al., 2008).

Research on the effect of saponins on the process of methanogenesis should have in view the rumen ecosystem as a complex that is largely responsible for the production performance of ruminants. Solutions that do not disturb the ecosystem balance should be searched for, such as long-standing research by García-González et al. $(2008,2010)$, who in the in vitro conditions selected carriers of saponins that modulate the fermentation processes in the rumen and thus reduce the process of methanogenesis without the adverse effect on the animal productivity.

\section{CONCLUSIONS}

Although many research centres perform research on the potential of phytofactors to mitigate rumen ammonia and methane production, the multitude of factors that may have influence on the rumen processes, hinders fast solution of the bothering problem, and many questions that arise after the analysis of the obtained results 
sometimes remain unanswered. In conclusion of the conducted analysis and in designing another study, the following factors that have influence on the obtained results should be taken into consideration: 1. microorganism adaptation ability, 2. mode of action, 3. type of diet fed, 4. production conditions and purpose, 5. modern molecular procedures, and 6. modern analytical methods.

\section{REFERENCES}

Agarwal N., Shekhar C., Kumar R., Chaudhary L.C., Kamra D.N., 2009. Effect of peppermint (Mentha piperita) oil on in vitro methanogenesis and fermentation of feed with buffalo rumen liquor. Anim. Feed Sci. Tech. 148, 321-327

Attwood G. T., Reilly K., 1995. Identification of proteolytic rumen bacteria isolated from New Zealand cattle. J. Appl. Bacteriol. 79, 22-29

Baah J., Ivan M., Hristov A.N., Koenig K.M., Rode L.M., McAllister T.A., 2007. Effects of potential dietary antiprotozoal supplements on rumen fermentation and digestibility in heifers. Anim. Feed Sci. Tech. 137, 126-137

Benchaar C., Calsamiglia S., Chaves A.V., Fraser G.R., Colombatto D., McAllister T.A., Beauchemin K.A., 2008. A review of plant-derived essential oils in ruminant nutrition and production. Anim. Feed Sci. Tech. 145, 209-228

Borchers R., 1965. Proteolytic activity of rumen fluid in vitro. J. Anim. Sci. 24, 1033-1038

Broderick G.A., Balthrop J.E., 1979. Chemical inhibition of amino acid deamination by ruminal microbes in vitro. J. Anim. Sci. 49, 1101-1111

Busquet M., Calsamiglia S., Ferret A., Kamel C., 2006. Plant extracts affect in vitro rumen microbial fermentation. J. Dairy Sci. 89, 761-771

Busquet M., Calsamiglia S., Ferret S., Kamel C., 2005. Screening for the effects of natural plant extracts and secondary plant metabolites on rumen microbial fermentation in continuous culture. Anim. Feed Sci. Tech. 123, 597-613

Calsamiglia S., Busquet M., Cardozo P.W., Castillejos L., Ferret A., 2007. Invited Review: Essential oils as modifiers of rumen microbial fermentation. J. Dairy Sci. 90, 2580-2595

Cardozo P.W., Calsamiglia S., Ferret A., Kamel C., 2004. Effects of natural plant extracts on ruminal protein degradation and fermentation profiles in continuous culture. J. Anim. Sci. 82, 3230-3236

Castillejos L., Calsamiglia S., Ferret A., 2006. Effect of essential oils active compounds on rumen microbial fermentation and nutrient flow in in vitro systems. J. Dairy Sci. 89, 2649-2658

Castillo A.R., Kebraeb E., Beever D.E., Barbi J.H., Sutton J.D., Kirby H.C., France J., 2001. The effect of protein supplementation of nitrogen utilization in lactating dairy cows fed grass silage diets. J. Anim. Sci. 79, 247-253

Chaves A.V., He M. L., Yang W. Z., Hristov A. N., McAllister T. A., Benchaar C., 2008. Effects of essential oils on proteolytic, deaminative and methanogenic activities of mixed ruminal bacteria Can. J. Anim. Sci. 88, 117-122

Cheeke P.R., 1996. Biological effects of feed and forage saponins and their impact on animal production. Adv. Exp. Med. Biol. 405, 377-385

Cieślak A., Zmora P., Nowakowska A., Szumacher-Strabel M., 2009. Limonene affect rumen methanogenesis. Acta Bioch. Pol. 56, Suppl. 2, 59-60

Crane A., Nelson W.O., Brown R.E., 1957. Effects of D-limonene and a-D-pinene on in vitro carbohydrate dissimilation and methane formation by rumen bacteria. J. Dairy Sci. 40, 13171323 


\section{PHYTOFACTORS - RUMEN AMMONIA AND METHANE PRODUCTION}

Davidson P.M., Naidu A.S., 2000. Phyto-phenols. In: A.S. Naidu (Editor). Natural Food Antimicrobial Systems. CRC Press, Boca Raton, FL, pp. 265-294

Dong G.Z., Wang X.J., Liu Z.B., Wang F., 2010. Effects of pytogenic products on in vitro rumen fermentation and methane emission in goats. J. Anim. Feed Sci. 19, 218-229

European Commission, 2003. Regulation (EC) No. 1831/2003 of the European Parliament and of the Council of 22 September 2003 on Additives for Use in Animal Nutrition. Off. J. Eur. Union L: L268/29-L268/43

Evans J.D., Martin S.A., 2000. Effects of thymol on ruminal microorganisms. Curr. Microbiol. 41, 336-340

Francis G., Kerem Z., Makkar H.P.S., Becker K., 2002. The biological action of saponins in animal systems: a review. Brit. J. Nutr. 88, 587-605

García-González R., González J.S., López S., 2010. Decrease of ruminal methane production in Rusitec fermenters through the addition of plant material from rhubarb (Rheum spp.) and alder buckthorn (Frangula alnus). J. Dairy Sci. 93, 3755-3763

García-González R., López S., Fernández M., González J. S., 2008. Dose-response effects of Rheum officinale root and Frangula alnus bark on ruminal methane production in vitro. Anim. Feed Sci. Tech. 145, 319-334

Goel G., Makkar H.P.S., Becker K., 2008. Changes in microbial community, structure, methanogenesis and rumen fermentation in response to saponin-rich fractions from different plant materials. $\mathrm{J}$. Appl. Microbiol. 105, 770-777

Greathead H., 2003. Plants and plant extracts for improving animal productivity. Proc. Nutr. Soc. $62,279-290$

Guo Y.Q., Liu J.X., Lu Y., Zhu W.Y., Denman S.E., McSweeney C.S., 2008. Effect of tea saponin on methanogenesis, microbial community structure and expression of mcrA gene, in cultures of rumen microorganisms. Lett. Appl. Microbiol. 47, 421-426

Hart K.J., Yáñez-Ruiz D.R., Duval S.M., McEvan N.R., Newbold C.J., 2008. Plant extracts to manipulate rumen fermentation. Anim. Feed Sci. Tech. 147, 8-35

Hegarty R.S., 1999. Reducing rumen methane emission through elimination of rumen protozoa. Aust. J. Agr. Res. 50, 1321-1327

Hess H.D., Beuret R.A., Lotscher M., Hindrichsen K.I., Machmüller A., Carulla J.E., Lascano C.E., Kreuzer M., 2004. Ruminal fermentation, methanogensis and nitrogen utilization of sheep receiveing tropical grass hay-concentrate diet offered with Sapindus saponaria fruits and Cratylia argentea foliage. Anim. Sci. 79, 177-189

Hess H.D., Kreuzer M., Diaz T.E., Lascano C.E., Carulla J.E., Soliva C.R., Machmüller A., 2003. Saponin rich tropical fruits affect fermentation and methanogenesis in faunated and defaunated rumen fluid. Anim. Feed Sci. Tech. 109, 79-94

Hess H.D., Monsalve L.M., Lascano C.E., Carulla J.E., Diaz T.E., Kreuzer M., 2003a. Supplementation of a tropical grass diet with forage legumes and Sapindus saponaria fruits: effects on in vitro ruminal nitrogen turnover and methanogenesis. Aust. J. Agr. Res. 54, 703-713

Hobson P.N., 1969. Rumen bacteria. In: J.R. Norris, D.W. Ribbons (Editors). Methods in Microbiology, Vol. 3B. Academic Press Ltd., London, pp.133-149

Hoffman C., Evans C.A., 1911. The use of spices as preservatives. J. Ind. Eng. Chem. 3, 835-838

Holtshausen L., Chaves A.V., Beauchemin K.A., McGinn S.M., McAllister T.A.,Odongo N.E., Cheeke P.R., Benchaar C., 2009. Feeding saponin-containing Yucca schidigera and Quillaja saponaria to decrease enteric methane production in dairy cows. J. Dairy Sci. 92, 2809-2821

Hristov A.N., Grandeen K. L., Ropp J., Greer D., 2004. Effect of Yucca schidigera-based surfactant on ammonia utilization in vitro, and in situ degradability of corn grain. Anim. Feed Sci. Tech. $115,341-355$ 
Hristov A.N., Ivan M., Neill L., McAllister T.A., 2003. A survey of potential bioactive agents for reducing protozoal activity in vitro. Anim. Feed Sci. Tech. 105, 163-184

Hristov N.A., McAllister T.A., Van Herk F.H., Cheng K.J., Newbold C.J., Cheeke P.R., 1999. Effect of Yucca schidigera on ruminal fermentation and nutrient digestion in heifers. J. Anim. Sci. 77, 2554-2563

Hu W.L., Liu J.X., Ye J.A., Wu Y.M., Guo Y.Q., 2005. Effect of tea saponin on rumen fermentation in vitro. Anim. Feed Sci. Tech. 120, 333-339

Hungate R.E., 1967. Hydrogen as an intermediate in the rumen fermentation. Arch. Microbiol. 40, 952-958

Islam M. R., Begum J., 1997. Short review of global methane situation and of facilities to reduce in ruminants in third world countries. Asian J. Anim. Sci. 10, 157-163

Ivan M., Dayrell M.D., Mahadevan S., Hidiroglou M., 1992. Effect of bentonite on wool growth and nitrogen metabolism in fauna-free and faunated sheep. J. Anim. Sci. 70, 3194-3202

Ivan M., Koenig K.M., Teferedenge B., Newbold C.J., Entz T., Rode L.M., Ibrahim M., 2004. Effects of the dietary Enterolobium cyclocarpum foliage on the population dynamics of rumen ciliate protozoa in sheep. Small Ruminant Res. 52, 81-91

Ivan M., Mir P.S., Mir Z., Koenig K.M., Newbold C.J., Entz T., Rode L.M., Ibrahim M., 2002a. Use of dietary saponins or vegetable oil to control protozoal populations in the rumen of sheep. In: $6^{\text {th }}$ International ICABR Conference. Ravello (Italy), pp. 1-12

Ivan M., Neill L., Forster R., Alimon R., Rode L.M., Entz T., 2000b. Effects of Isotricha, Dasytricha, Entodinium, and total fauna on ruminal fermentation and duodenal flow in wethers fed different diets. J. Dairy Sci. 83, 776-787

James T., Meyer D., Esparza E., DePeters E.J., Perez-Monti H., 1999. Effects of dietary nitrogen manipulation on ammonia volatilization from manure from Holstein heifers. J. Dairy Sci. 82, 2430-2439

Jensen B.B., 1996. Methanogenesis in monogastric animals. Environ. Monit. Assess. 42, 99-112

Johnson D.E., Ward G.M., 1996. Estimates of animal methane emissions. Environ. Monit. Assess. 42, 133-141

Johnson K.A., Johnson D.E., 1995. Methane emissions from cattle. J. Anim. Sci. 73, 2483-2492

Kreuzer M., Soliva C.R., 2008. Nutrition: key to methane mitigation in ruminants. Proc. Soc. Nutr. Physiol. 17, 168-171

Lapierre H., Berthiaume R., Ragio R., Thivierge M.C., Doepel M.C., Pacheco L., Debreuil P., Lobley G.E., 2005. The route of absorbed nitrogen into milk protein. Anim. Sci. 80, 11-22

Leng R.A., Bird S.H., Klieve A., Choo B.S., Ball F.M., Asefa G., Brumby P., Mudgal V.D., Chaudhry U.B., Haryono S.U., Hendrato N., 1992. The potential for tree forage supplements to manipulate rumen protozoa to enhance protein-to-energy ratios in ruminants fed on poor quality forages. In: Legume Tees and Other Fodder Trees as Protein Sources for Livestock. FAO, Rome

Lila Z.A., Mohammed N., Kanda S., Kamada T., Itabashi H., 2003. Effect of sarsaponin on ruminal fermentation with particular reference to methane production in vitro. J. Dairy Sci. 86, 33303336

Lila Z.A., Mohammed N., Kanda S., Kurihara M., Itabashi H., 2005. Sarsaponin effects on ruminal fermentation and microbes, methane production, digestibility and blood metabolites in steers. Asian-Austr. J. Anim. Sci. 12, 1746 (Abstr.)

Macheboeuf D., Morgavi D.P., Papon Y., Mousset J.-L., Arturo-Schaan M., 2008. Dose-response effects of essential oils on in vitro fermentation activity of the rumen microbial population. Anim. Feed Sci. Tech. 145, 335-350 


\section{PHYTOFACTORS - RUMEN AMMONIA AND METHANE PRODUCTION}

Mao H.L., Wang J.K., Zhou Y.Y., Liu J.X., 2010. Effects of addition of tea saponins and soyabean oil on methane production, fermentation and microbial population in the rumen of growing lambs. Livest. Sci. 129, 56-62

Martin C., Morgavi D.P., Doreau M., 2010. Methane mitigation in ruminants: from microbe to the farm scale. Animal 4, 351-365

McAllister T.A., Newbold C.J., 2008. Redirecting rumen fermentation to reduce methanogenesis. Aust. J. Exp. Agr. 48, 7-13

McIntosh F.M., Williams P., Losa R., Wallace R.J., Beever D.A., Newbold C.J., 2003. Effects of essential oils on ruminal microorganisms and their protein metabolism. Appl. Environ. Microbiol. 69, 5011-5014

Miles C.O., Wilkins A.L., Munday S.C., Holland P.T., Smith B.L., Lancaster M.J., Embling P.P., 1992. Identification of the calcium salt of epismilagenin beta-D-glucuronide in the bile crystals of sheep affected by Panicum-dichotomiflorum and Panicum-schinzii toxicoses. J. Agr. Food Chem. 40, 1606-1609

Morgavi D.P., Jouany J.P., Martin C., 2008. Changes in methane emission and rumen fermentation parameters induced by refaunation in sheep. Aust. J. Exp. Agr. 48, 69-72

Nagy J.G., Tengerdy R.P., 1968. Antibacterial action of essential oils of Artemisia as an ecological factor. II. Antibacterial action of the volatile oils of Artemisia tridentata (Big sagebrush) on bacteria from the rumen of mule deer. Appl. Microbiol. 16, 441-444

Newbold C.J., ElHassan S.M., Wang J., Ortega M.E., Wallace R.J., 1997. Influence of foliage from African multipurpose trees on activity of rumen protozoa and bacteria. Brit. J. Nutr. 78, 237249

Newbold, C.J., Wallace R.J., Watt N.D., Richardson A.J., 1988. The effect of the novel ionophore tetronasin (ICI 139603) on ruminal microorganisms. Appl. Environ. Microbiol. 54, 544-547

Newman D.J., Cragg G.M., Snader K.M., 2000. The influence of natural products upon drug discovery. Nat. Prod. Rep. 17, 215-234

Ningrat R.W.S., Garnsworthy P.C., Newbold C.J., 2002. Saponin fractions in Sapindus rarak: effects on rumen microbes. Reprod. Nutr. Develop. 42, S82 (Abstr.)

Odenyo A.A., Osuji P.O., Karanfil O., 1997. Effect of multipurpose tree (MPT) supplements on ruminal ciliate protozoa. Anim. Feed Sci. Tech. 67, 169-180

Ogino A., Orito H., Shimadad K., Hirooka H., 2007. Evaluating environmental impacts of the Japanese beef cow-calf system by the life cycle assessment method. J. Anim. Sci. 78, 424-432

Oh H.K., Sakai T., Jones M.B., Longhurst W.M., 1967. Effect of various essential oils isolated from Douglas Fir Needles upon sheep and deer rumen microbial activity. Appl. Microbiol. 15, 777 784

Ohene-Adjei S., Chaves A.V., McAllister T.A., Benchaar C., Teather R.M., Forster R.J., 2008. Evidence of increased diversity of methanogenic archaea with plant extract supplementation. Microbial Ecol. 56, 234-242

Patra A.K., Saxena J., 2009. Dietary phytochemicals as rumen modifiers: a review of the effects on microbial populations. Anton. Leeuwenhoek Int. J. Gen. M. 96, 369-375

Patra A.K., Saxena J., 2010. A new perspective on the use of plant secondary metabolites to inhibit methanogenesis in the rumen. Phytochemistry 71, 1198-1222

Pen B., Sar C., Mwenya B., Kuwaki K., Morikawa R., Takahashi J., 2006. Effects of Yucca schidigera and Quillaja saponaria extracts on in vitro ruminal fermentation and methane emission. Anim. Feed Sci. Tech. 129, 175-186

Pen B., Takaura K., Yamaguchi S., Asa R., Takahashi J., 2007. Effects of Yucca schidigera and Quillaja saponaria with or without b-1, galactooligosaccharides on ruminal fermentation, methane production and nitrogen utilization in sheep. Anim. Feed Sci. Tech. 138, 75-88 
Place S.E., Mitloehner F.M., 2010. Invited review: Contemporary environmental issues: A review of the dairy industry's role in climate change and air quality and the potential of mitigation through improved production efficiency. J. Dairy Sci. 93, 3407-3416

Russell J.B., Strobel H.J., Chen G., 1988. Enrichment and isolation of a ruminal bacterium with a very high specific activity of ammonia production. Appl. Environ. Microbiol. 54, 872-877

Stewart C.S., Flint H.J., Bryant M.P., 1997. The rumen bacteria. In: P. N. Hobson, C.S. Stewart (Editors). The Rumen Microbial Ecosystem. Blackie Academic and Professional Publ., London, pp. 10-55

Śliwiński B., Kreuzer M., Wettstein H.R., Machmüller A., 2002. Rumen fermentation and nitrogen balance of lambs fed diets containing plant extracts rich in tannins and saponins, and associated emission of nitrogen and methane. Arch. Anim. Nutr. 56, 379-392

Śliwiński B.J., Soliva C.R., Machmüller A., 2002a. Efficacy of plant rich in secondary constituents to modify rumen fermentation. Anim. Feed Sci. Tech. 101, 101-114

Teferedegne B., 2000. New perspectives on the use of tropical plants to improve ruminant nutrition. Proc. Nutr. Soc. 59, 209-214

Teferedegne B., McIntosh F., Osuji P.O., Odenyo A., Wallace R.J., Newbold C.J., 1999. Influence of foliage from different accessions of the sub-tropical leguminous tree, Sesbania sesban, on ruminal protozoa in Ethiopian and Scottish sheep. Anim. Feed Sci. Tech. 78, 11-20

Tyler V.E., 1999. Phytomedicines: back to the future. J. Nat. Prod. 62, 1589-1592

Ushida K., Jouany J.P., 1996. Methane production associated with rumen-ciliated protozoa and its effect on protozoan activity. Lett. Appl. Microbiol. 23, 129-132

VandeHaar M.J., St-Pierre N., 2006. Major advances in nutrition: relevance to the sustainability of the dairy industry. J. Dairy Sci. 89, 1280-1291

Wallace R.J., 2004. Symposium on 'Plants as animal foods: a case of catch 22?'. Antimicrobial properties of plant secondary metabolites. Proc. Nutr. Soc. 63, 621-629

Wallace R.J., Arthaud L., Newbold C.J., 1994. Influence of Yucca-schidigera extract on ruminal ammonia concentrations and ruminal microorganisms. Appl. Environ. Microbiol. 60, 17621767

Wang C.J., Wang S.P., Zhou H., 2009. Influences of flavomycin, ropadiar, and saponin on nutrient digestibility, rumen fermentation, and methane emission from sheep. Anim. Feed Sci. Tech. 148, 157-166

Wina E., Muetzel S., Hoffmann E., Makkar H.P.S., Becker K., 2005. Saponins containing methanol extract of Sapindus rarak affect microbial fermentation, microbial activity and microbial community structure in vitro. Anim. Feed Sci. Tech. 121, 159-174

Wolin M.J., Miller T.L., 1988. Microbe-microbe interaction. In: P. N. Hobson (Editor). The Rumen, Microbial Ecosystem. Elsevier Applied Science. London, pp. 343-459

Wuebbles D.J., Hayhoe K., 2002. Atmospheric methane and global change. Earth-Sci. Rev. 57, 177-210

Zhu W.Y., Mao S.Y., Liu J.X., Cheng Y.F., Iqbal M.F., Wang J.K., 2007. Diversity of methanogens and their interactions with other microorganisms in methanogenesis in the rumen. In: Proceedings of the VII International Symposium on the Nutrition of Herbivores. China Agriculture University Press, pp. 17-22 